\author{
Karolina Bródka \\ Irena Szadkowska-Stańczyk
}

\title{
FACTORS INFLUENCING BIOSAFETY LEVEL AND LAI AMONG THE STAFF OF MEDICAL LABORATORIES
}

\author{
CZYNNIKI WPŁYWAJĄCE NA POZIOM BEZPIECZEŃSTWA I INFEKCJE \\ WŚRÓD PRACOWNIKÓW LABORATORIÓW DIAGNOSTYCZNYCH
}

Nofer Institute of Occupational Medicine / Instytut Medycyny Pracy im. prof. J. Nofera, Łódź, Poland

Department of Environmental Health Hazards / Zakład Środowiskowych Zagrożeń Zdrowia

\begin{abstract}
Background: The aim of the study was to assess the biological risks of medical laboratory employees with particular focus on laboratory acquired infection (LAI), activities having the greatest risk, accidents with biological material, post exposure procedure, preventive measures and workers' knowledge about biological exposure. Materials and Methods: The study involved 9 laboratories. A questionnaire survey was attended by 123 employees and 9 heads of these units with the use of two questionnaires for laboratory workers and the managers. Results: $32.5 \%$ of the respondents (40 persons) had an accident at least once. Needlestick or a broken glass injury covered $18.7 \%$ respondents (23 persons), while splashing the skin, mucous membranes or conjunctivae related to $22.8 \%$ (28 persons). Among the employees who had an accident, only $45 \%$ of the respondents (18 persons) reported this to the manager. Microbes dominant in the biological material were known only to 57 respondents (46.3\%), less than half could correctly give an example of a disease ( 57 persons, $46.3 \%$ ). More than half of the respondents admitted that they do not know all of the possible routes of infection while working in the laboratory ( 68 persons, 55.3\%). Conclusions: In the study population, a high incidence of accidents was observed, usually during blood sampling and transfer of biological material. Condition of the workers' equipment with personal protective measures and laboratory facilities in devices to reduce the risk of infection and procedures for handling the potentially infectious material should be considered as insufficient. Lack of basic knowledge of the employees about biohazards at workplaces was shown. Med Pr 2013;64(4):473-486
\end{abstract}

Key words: medical laboratories, occupational biohazards, Laboratory Acquired Infections, blood exposure, post exposure prophylaxis, questionnaire survey

\section{STRESZCZENIE}

Wstęp: Celem badania była ocena zagrożenia pracowników laboratoriów diagnostycznych szkodliwymi czynnikami biologicznymi, ze szczególnym uwzględnieniem infekcji (LAI - laboratory acquired infection), czynności o największym ryzyku, wypadków z udziałem materiału biologicznego, postępowania poekspozycyjnego i stosowanych środków profilaktycznych oraz wiedzy o narażeniu na czynniki biologiczne. Materiał i metody: Badaniem objęto 9 laboratoriów. Ogółem w badaniu wzięło udział 123 pracowników i 9 kierowników tych jednostek. Zastosowano 2 kwestionariusze - dla pracowników i kierowników. Wyniki: Aż 32,5\% badanych (40 osób) przynajmniej raz uległo wypadkowi z udziałem potencjalnie zakaźnego materiału biologicznego. Zakłucia igłą zabrudzoną krwią bądź skaleczenia szkłem z potłuczonej probówki z krwią dotyczyły 18,7\% badanej grupy (23 osoby), natomiast zachlapanie skóry, błon śluzowych bądź spojówek materiałem biologicznym - 22,8\% (28 osób). Wśród pracowników, którzy ulegli wypadkowi, tylko $45 \%$ badanych (18 osób) zgłosiło wypadek przełożonemu. Mniej niż połowa potrafiła wskazać drobnoustroje dominujące w opracowywanym materiale biologicznym (57 osób, 46,3\%) i tyle samo osób potrafiło prawidłowo podać przykład choroby przez nie wywoływanej (57 osób, 46,3\%). Ponad połowa badanych przyznała, że nie zna wszystkich możliwych dróg zakażenia (68 osób, 55,3\%). Wnioski: Odnotowano wysoką częstość wypadków z udziałem czynnika biologicznego, najczęściej podczas pobierania krwi i przenoszenia materiału biologicznego. Stan wyposażenia pracowników w środki ochrony indywidualnej oraz wyposażenie laboratoriów w urządzenia zmniejszające ryzyko infekcji, a także w procedury postępowania z materiałem potencjalnie zakaźnym należy uznać za niewystarczający. Wykazano braki w elementarnej wiedzy pracowników o potencjalnych drogach zakażenia podczas wykonywania prac z materiałem biologicznym, o skutkach zdrowotnych i właściwych zachowaniach ograniczających ryzyko infekcji. Med. Pr. 2013;64(4):473-486

Słowa kluczowe: laboratoria diagnostyczne, ryzyko zawodowe, infekcje, zawodowa ekspozycja na krew, postępowanie poekspozycyjne, badanie ankietowe

Corresponding author / Autorka do korespondencji: Anna Kozajda, Department of Environmental Health Hazards, Nofer Institute of Occupational Medicine, św. Teresy 8, 91-348 Łódź, Poland, e-mail: anias@imp.lodz.pl

Received: 2013, September 2, accepted: 2013, October 13

The study has been prepared under a project financed from statutory activity grant No. IMP 3.3/2010 - "The identification of exposure to biological agents in medical diagnostic laboratories". 


\section{INTRODUCTION}

Employees of clinical diagnostic laboratories are professionally burdened with a particularly high risk of infection resulting from direct contact with potentially infectious material. Pathogenic microorganisms (bacteria, viruses, fungi and parasites) can enter an employee's system as a result of:

cutting the skin with a used needle or other contaminated sharp instrument,

the splashing or sprinkling of biological material onto the skin or mucous membranes,

- swallowing or transferring biological material to the mouth or eyes with dirty hands or contaminated instruments,

- inhaling aerosols containing infectious agents (1).

In order to maximally reduce the risk of infection at work, global expert organizations have developed a number of recommendations and indications. They have been implemented in some countries to a varying extent, including Poland (1-9). According to the report by the Centers for Disease Control and Prevention (CDC), exposure in laboratories is much more frequent than commonly believed, and the risk of exposure to a potentially infectious biological material is an integral part of laboratory staffs' work. A diagnostic laboratory can be a safe workplace if safety-at-work standards are met, and all of the procedures, easily accessible and comprehensible, enforced by the employer and followed by the employees (9).

The actual frequency of hazardous events and accidents involving biological material potentially contaminated with pathogenic microorganisms in laboratory staff and other medical professionals has not been identified in Poland. This is due to the lack of a central register of such events and low reporting rate of the described exposure by employees. In the world and Polish literature on the subject, the problem of the high frequency of exposure to potentially infectious material, and the low reporting rate, is more thoroughly investigated in the case of healthcare professionals (physicians, especially surgeons, nurses and midwives) (10-16). In recent years, studies on the work safety of laboratory staff in the context of exposure to potentially infectious biological material have been carried out in developing countries (17-21), but the problem also concerns highly industrialised countries.

The literature on the subject contains detailed reports assessing the risk of contracting an infection at work (Laboratory Acquired Infection - LAI) - both in general and in respect of particular infectious agents - especially such bacteria as: Brucella spp., Salmonella spp., Shigella spp., Neisseria meningitidis, Mycobacterium tuberculosis, Francisella tularensis, Bacillus anthracis and Escherichia coli, such viruses as: HBV, HCV and HIV, and also some parasites (22-29). Clinical diagnostic laboratory staff are the second group of professionals, after nurses, bearing the highest risk of being infected with HIV $(26,30)$. Parszuto et. al. (31) analysed occupational infections with hepatitis types $\mathrm{B}$ and $\mathrm{C}$ among healthcare professionals in one of Poland's regions in the years 19992009. The research revealed that, of all of the healthcare professions, the highest annual incidence rates for hepatitis types $\mathrm{B}$ and $\mathrm{C}$ are recorded among laboratory staff (laboratory assistant - 59.9, medical analytics technician/ assistant - 53.4, medical analytics specialist with an MSc title -10.8 per 10 thousand employees).

The purpose of this study was to identify the areas with the highest risk of infection in medical diagnostic laboratories, to assess the knowledge of staff on the risk of infections at work, to evaluate the actual frequency of hazardous events and accidents involving potentially infectious biological material in medical diagnostic laboratories and to analyse the implementation of post exposure procedures and preventive measures applied by laboratories.

\section{MATERIAL AND METHODS}

The research included 9 medical diagnostic laboratories located in a large agglomeration. An anonymous questionnaire survey covered a total number of 123 employees and 9 managers of the laboratories. The questionnaire return rate, in particular facilities, ranged from $15 \%$ to $90 \%$, with an average value for the entire survey amounting to approx. $60 \%$. In all of the surveyed laboratories, human material was analysed, and three also carried out analyses of animal material.

\section{The research tool}

For the purposes of the study a research tool was prepared in the form of two questionnaires: one for laboratory employees who had direct contact with potentially infectious biological material at their work (30 questions) and the other for the managers (48 questions). Within the survey, the obtained information included:

- the knowledge of employees on potential hazards and possible health effects and prophylaxis,

the provision of equipment and appliances minimising health risks to the employees, 
the technical condition of laboratory rooms,

employees' activities,

the occurrence of accidents and hazardous events involving biological agents,

the protection measures applied (technical, organizational and medical),

the employees' behaviour which could increase the risk.

\section{Data analysis}

The information collected in the survey were coded and entered into the database created in MS Excel 2003 (Microsoft, Redmond, USA). The aggregated data was pre- sented in the form of absolute numbers and in percentages in relation to the entire surveyed group, and, in the description of the surveyed population, the arithmetic mean $(\mathrm{AM})$, median $(\mathrm{Me})$ and range $(\mathrm{min}, \max )$ were applied.

\section{The characteristics of the surveyed population}

The survey included 3 narrow-profile and 6 broad-profile laboratories. In terms of the number of analyses carried out per year, 4 of the surveyed laboratories were classified as small, 2 as medium and 3 as large units. The types of laboratories participating in the survey are presented in Table 1.

Table 1. Types of laboratories and employees under the study

Tabela 1. Typy laboratoriów i pracownicy objęci badaniem

\begin{tabular}{|c|c|c|c|}
\hline $\begin{array}{c}\text { Laboratory characteristics } \\
\text { Cechy laboratorium }\end{array}$ & $\begin{array}{l}\text { Laboratories } \\
\text { Laboratoria } \\
\qquad(\mathrm{N}=9) \\
{[\mathrm{n}]}\end{array}$ & \multicolumn{2}{|c|}{$\begin{array}{l}\text { The study group } \\
\text { Grupa badana } \\
\qquad(\mathrm{N}=123)\end{array}$} \\
\hline \multicolumn{4}{|l|}{ Open / Czynne } \\
\hline 5 days/week / 5 dni/tydzień & 2 & 23 & 18.7 \\
\hline 7 days/week / 7 dni/tydzień & 4 & 61 & 49.6 \\
\hline Narrow profile / Wąskoprofilowe & 3 & 27 & 22.0 \\
\hline Broad profile / Szerokoprofilowe & 6 & 96 & 78.0 \\
\hline \multicolumn{4}{|l|}{ Tests in the year / Badania w roku [n] } \\
\hline $500000-1000000$ & 3 & 55 & 44.7 \\
\hline
\end{tabular}

Table 2. The characteristics of study group

Tabela 2. Charakterystyka badanej grupy

\begin{tabular}{|c|c|c|}
\hline $\begin{array}{l}\text { Category } \\
\text { Kategoria }\end{array}$ & \multicolumn{2}{|c|}{$\begin{array}{l}\text { The study group } \\
\text { Grupa badana } \\
\qquad(\mathrm{N}=123)\end{array}$} \\
\hline \multicolumn{3}{|l|}{ Gender / Płeć } \\
\hline female / kobieta & 115 & 93.5 \\
\hline \multicolumn{3}{|l|}{ Education level / Wykształcenie } \\
\hline primary/vocational / podstawowe / zasadnicze zawodowe & 3 & 2.4 \\
\hline secondary technical/general / postsecondary / średnie techniczne/ogólne / policealne & 75 & 61.0 \\
\hline
\end{tabular}


Table 2. The characteristics of study group - cont.

Tabela 2. Charakterystyka badanej grupy - cd.

\begin{tabular}{|c|c|c|c|}
\hline & $\begin{array}{l}\text { Category } \\
\text { Kategoria }\end{array}$ & \multicolumn{2}{|c|}{$\begin{array}{l}\text { The study group } \\
\text { Grupa badana } \\
\qquad(\mathrm{N}=123)\end{array}$} \\
\hline \multicolumn{4}{|c|}{$\begin{array}{l}\text { on the current workplace / na aktualnym stanowisku pracy } \\
(\mathrm{AM}=18.1, \mathrm{Me}=21, \min -\max : 1-38)\end{array}$} \\
\hline $6-15$ & & 23 & 18.7 \\
\hline $16-25$ & & 43 & 35.0 \\
\hline$\geq 26$ & & 38 & 30.9 \\
\hline \multicolumn{4}{|c|}{ total in laboratories / w laboratoriach ogółem $(\mathrm{AM}=20.9, \mathrm{Me}=23$, min-max: 1-38) } \\
\hline $16-25$ & & 57 & 46.3 \\
\hline$\geq 26$ & & 42 & 34.1 \\
\hline
\end{tabular}

$\mathrm{AM}$ - arithmetic mean / średnia arytmetyczna.

$\mathrm{Me}$ - mediana.

min-max - range / zakres.

93.5\% of the surveyed employees were women and $6.5 \%$ were men. The largest number of respondents had secondary education (61\%), slightly less had higher education (36.6\%), and the least numerous group had primary or basic vocational education $(2.4 \%)$. Taking into consideration seniority in the current laboratory ( $\leq 5$ years, $6-15$ years, $16-25$ years and $\geq 26$ years), the percentage of employees amounted to $15.4 \%, 18.7 \%$, $35 \%$ and $30.9 \%$, respectively. The structure of the total seniority in diagnostic laboratories showed that the surveyed employees worked longer in their profession. The average seniority in the current laboratory was 21 years, and the total seniority in laboratories amounted to 23 years in total. Detailed data characterising the surveyed population is provided in Table 2.

\section{RESULTS}

Only 57 of the surveyed (46.3\%) were able to identify microorganisms dominant in the biological material analysed by them. Less than half of the respondents were able to provide an example of a disease caused by microorganisms dominant in the biological material with which they had contact at work (57 persons, $46.3 \%$ - not in all cases were these the same persons who were able to identify the dominant microorganisms). Over half of the sur- veyed admitted that they did not know all of the possible infection routes in laboratory work (68 persons, 55.3\%). Among the remaining persons, who claimed that they knew all the infection routes ( 55 persons, $44.7 \%$ ), no one was able to enumerate all of them. The highest number of respondents mentioned blood-borne infections, i.e. needlestick injury / skin cutting (53 persons, 43.1\%) and inhalation (41 persons, 33.3\%).

Among the mentioned possible infection routes, there were mucous membranes, ingestion, intact skin and conjunctivae. Data concerning the analysis of the surveyed persons' knowledge on exposure to biological agents is presented in Table 3 .

Table 4 contains data on the frequency of hazardous events involving biological agents. The analysis of the obtained information shows that $1 / 3$ of those surveyed, throughout their work in the laboratory, experienced a hazardous event involving potentially infectious biological material (40 persons, 32.5\%). Injuries with a needle contaminated with blood or with glass from a broken tube containing blood were sustained by $1 / 5$ of the analysed group (23 persons, 18.7\%). Such events occurred once during the entire period of employment in the case of 20 persons (16.3\%), and twice, 3 and 4 times in the case of single persons (1 person each, $0.8 \%$ ). Contaminated needlestick inju- 
Table 3. Knowledge about the microorganisms dominant in biological material and diseases caused by them and all of the potential routes of infection

Tabela 3. Wiedza badanych pracowników dotycząca drobnoustrojów dominujących w materiale biologicznym i wywoływanych przez nie chorób oraz wszystkich potencjalnych dróg zakażenia

\begin{tabular}{|c|c|c|}
\hline $\begin{array}{l}\text { Knowledge about biological exposure } \\
\text { Wiedza o narażeniu na czynniki biologiczne }\end{array}$ & \multicolumn{2}{|c|}{$\begin{array}{l}\text { The study group } \\
\text { Grupa badana } \\
(\mathrm{N}=123)\end{array}$} \\
\hline Dominant microorganisms / Dominujące drobnoustroje & 57 & 46.3 \\
\hline Diseases / Choroby & 57 & 46.3 \\
\hline needlestick/cutting the skin / zakłucie/naruszenie powłok skórnych & 53 & 43.1 \\
\hline inhalation / wziewna & 41 & 33.3 \\
\hline mucosal / błony śluzowe & 14 & 11.4 \\
\hline
\end{tabular}

Table 4. The incidence of accidents involving hazardous biological agents during the entire period of employment in the laboratory Tabela 4. Częstość występowania niebezpiecznych zdarzeń z udziałem czynnika biologicznego w ciągu całego stażu pracy badanych pracowników w laboratorium

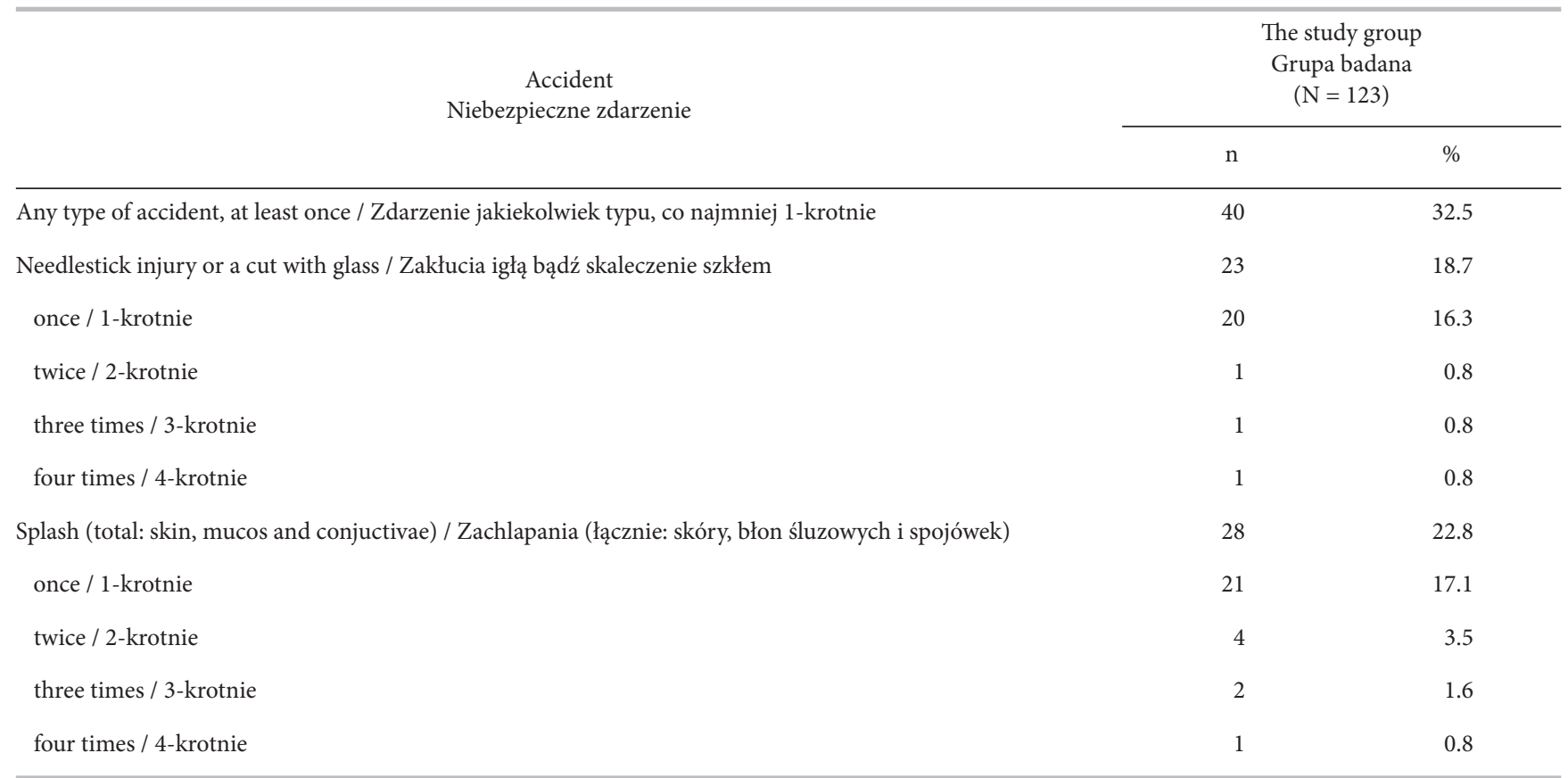

ries were most frequently recorded during taking blood samples for analysis and involved a finger or another part of the hand.

A slightly more numerous group of respondents stated that they had experienced a hazardous event at work, such as splashing the skin, mucous mem- branes (including oral cavity) or conjunctivae (28 persons, $22.8 \%$ ). Similarly to needlestick injuries, in the case of most respondents, the event took place once (21 persons, 17.1\%); it occurred twice for 4 persons (3.5\%), 3 times for 2 persons (1.6\%), and 4 times for only one person $(0.8 \%)$. The events most often hap- 
pened during taking a blood sample or other tests, inter alia, during the pipette sampling of, e.g. bacterial suspension, cultures, cutting the tubing containing blood for preparations, and pouring biological material into test tubes.

Managers of the analysed laboratories, when asked about hazardous events occurring in their facilities in the previous five years, usually did not know of any (6 laboratories). In one of the laboratories, the manager claimed that there was probably such an event but he does not remember anything, and in another, the manager knew there had been a needlestick injury but the instance had not been officially reported. Only in one laboratory, one occurrence of contaminated needlestick injury had been officially reported to the manager. It is worth mentioning that as many as one third of accidents involving biological agents reported by laboratory employees (25 persons, $36.8 \%$ ) took place in the two years preceding the survey.

Table 5 presents an analysis of the information obtained from the surveyed employees on the post exposure procedure following contact with potentially infectious biological material. Among the persons who had experienced a hazardous event during laboratory work, less than half reported this fact to the manager (18 persons, $45 \%)$, while the respondents who had experienced such an event more than once did not report any of them (8 persons, 20\%). In the latter group, most often, only the first accident was reported, and, seeing that the employer did not take any steps, the employees came to the conclusion that there was no point in reporting any further events.

Table 5. Post exposure prophylaxis within the group of laboratory employees who had an accident involving a biological agent Tabela 5. Postępowanie poekspozycyjne u pracowników laboratoriów, którzy ulegli niebezpiecznemu zdarzeniu z udziałem czynnika biologicznego

\section{Post exposure prophylaxis \\ Postępowanie poekspozycyjne}

Employees, who had an accident Badani, którzy doświadczyli zdarzenia $(\mathrm{N}=40)$

\begin{tabular}{|c|c|c|}
\hline \multicolumn{3}{|l|}{ The accident reported to the manager / Zgłoszenie zdarzenia przełożonemu } \\
\hline all accidents / wszystkie zdarzenia & 18 & 45.0 \\
\hline only some / tylko niektóre & 8 & 20.0 \\
\hline never / nigdy & 14 & 35.0 \\
\hline \multicolumn{3}{|l|}{ Visit to a doctor after the accident / Zgłoszenie się po zdarzeniu do lekarza } \\
\hline every time / za każdym razem & 12 & 30.0 \\
\hline not always / nie zawsze & 5 & 12.5 \\
\hline never / nigdy & 23 & 57.5 \\
\hline \multicolumn{3}{|l|}{ Visit at a doctor / Wizyta u lekarza } \\
\hline specialist in infectious diseases / specjalisty ds. chorób zakaźnych & 6 & 15.0 \\
\hline occupational health specialist / specjalisty medycyny pracy & 1 & 2.5 \\
\hline other specialist / innego & 6 & 15.0 \\
\hline lack of a visit / brak & 27 & 67.5 \\
\hline Post exposure prophylaxis implemented by a doctor / Wdrożone przez lekarza postępowanie poekspozycyjne & 13 & 32.5 \\
\hline antibody test / badanie przeciwciał & 12 & 30.0 \\
\hline active immunization / szczepienie szczepionką czynną & 1 & 2.5 \\
\hline passive immunization / szczepienie szczepionką bierną & 0 & 0 \\
\hline the application of antiviral drugs / podanie leków przeciwwirusowych & 3 & 7.5 \\
\hline A disease diagnosed as an result of the accident / Zdiagnozowana choroba jako skutek zdarzenia & 3 & 7.5 \\
\hline
\end{tabular}


Among the persons who had experienced a hazardous event, 17 (42.5\%) saw a doctor, but only 7 persons chose a doctor specialising in the proper field (6 persons a specialist in infectious diseases, 1 person - an occupational-health specialist). In the case of 14 persons (35\% of those surveyed who had had an accident involving a biological agent), the doctor administered post exposure procedure which, for 12 persons, (30\%) involved an antibody test, whereas 1 person was immunised (2.5\%), and 3 employees $(7.5 \%)$ received antiviral drugs.

In 3 employees (7.5\%), as a result of an accident involving a biological agent, a disease was diagnosed (two cases of hepatitis type $B$ and one case of hepatitis type $C$ ).

Table 6 contains the results of the analysis of the information on the use of (individual, technical and organizational) preventive measures by the employees minimising the risk of LAI. Masks with biological filters protecting the respiratory system were used by only $2.4 \%$ of those surveyed ( 3 persons); also masks without a filter (most often surgical masks) were used by a small group of 14 people (11.4\%). Disposable gloves (latex or vinyl) were worn by 114 persons (92.7\%). A considerable majority used only one pair (82 respondents; $66.7 \%$ ), while only 32 persons (26\%) used 2 or more pairs for some procedures. Eye protection was used by only $15.4 \%$ ( 19 respondents), and an almost identical number of the employees wore full face protection (visors) - 18 persons (14.6\%).

Protective clothing (lab coat or uniform) at work was worn by $81.3 \%$ of the surveyed ( 100 persons), which indicates that nearly $20 \%$ of this group did not use this basic form of protection. Lab coats with long sleeves and cuffs were used by only 23 employees (18.7\%). The rest of the respondents wore lab coats with long sleeves without cuffs (63 persons, $51.2 \%$ ) or with short sleeves (69 persons, 56.1\%). Some employees had protective clothing adjustable to the season of the year, i.e. with long and short sleeves.

Table 6. Preventive measures used in the laboratory employees under study

Tabela 6. Środki profilaktyczne stosowane w badanej grupie pracowników laboratoriów

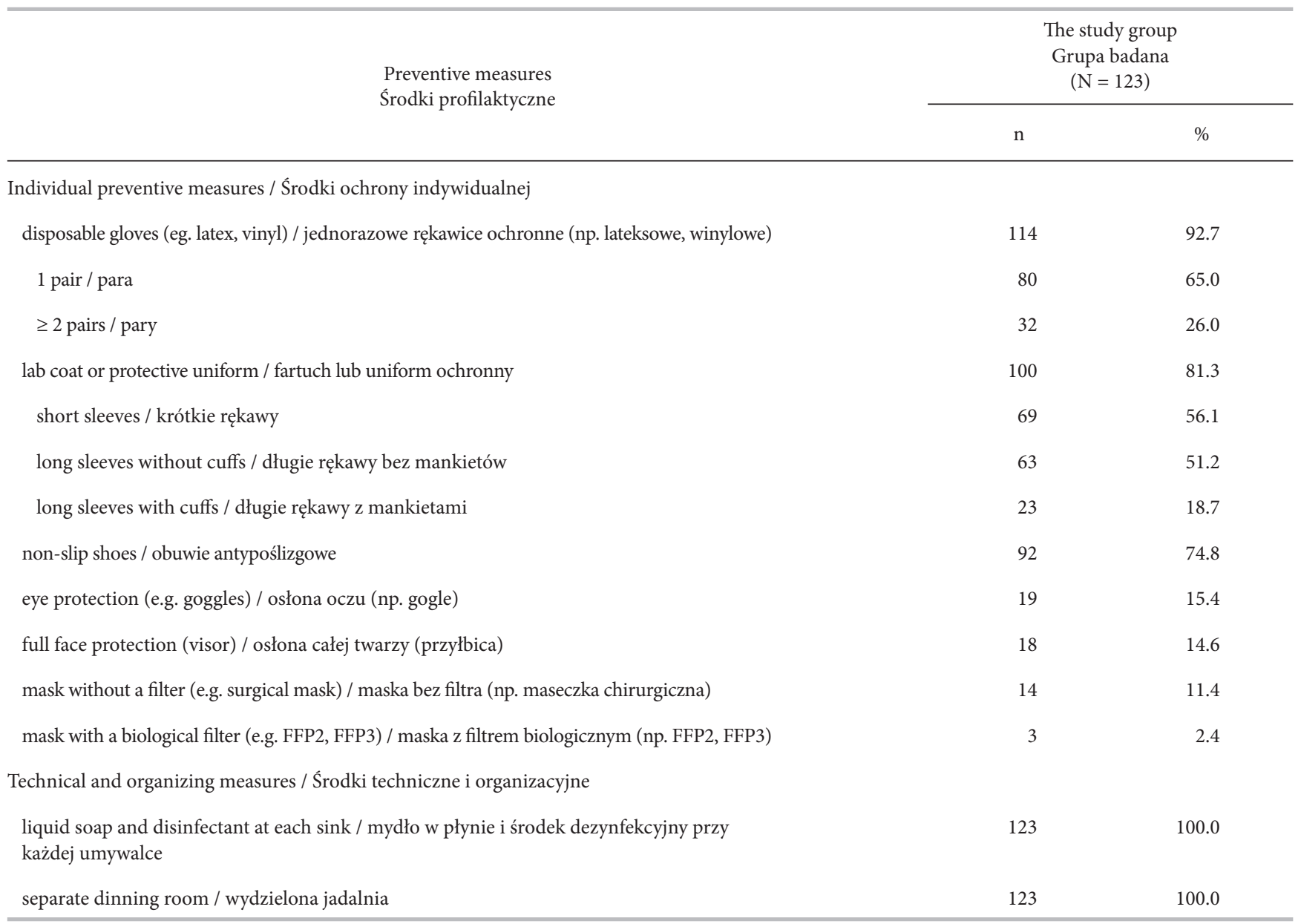


Table 6. Preventive measures used in the laboratory employees under study - cont.

Tabela 6. Środki profilaktyczne stosowane w badanej grupie pracowników laboratoriów - cd.

\begin{tabular}{|c|c|c|}
\hline \multirow[t]{2}{*}{$\begin{array}{l}\text { Preventive measures } \\
\text { Srodki profilaktyczne }\end{array}$} & \multicolumn{2}{|c|}{$\begin{array}{l}\text { The study group } \\
\text { Grupa badana } \\
(\mathrm{N}=123)\end{array}$} \\
\hline & $\mathrm{n}$ & $\%$ \\
\hline $\begin{array}{l}\text { impermeable to water and easily cleanable surfaces / nieprzepuszczalne dla wody i łatwo zmywalne } \\
\text { powierzchnie }\end{array}$ & 123 & 100.0 \\
\hline showers for employees / prysznice dla pracowników & 111 & 90.2 \\
\hline $\begin{array}{l}\text { sample collection facility outside the laboratory / punkt pobrań zorganizowany } \\
\text { na zewnątrz laboratorium }\end{array}$ & 92 & 74.8 \\
\hline equipment made of glass (cleaned and disinfected) / sprzęt ze szkła (myty i dezynfekowany) & 92 & 74.8 \\
\hline separate lockers for work and private clothes / oddzielne szafki na odzież roboczą i prywatną & 84 & 68.3 \\
\hline pass box for biological material / okno podawcze do materiału biologicznego & 81 & 65.9 \\
\hline $\begin{array}{l}\text { surfaces resistant to acids, alkalis and disinfectants / powierzchnie odporne na kwasy, zasady i środki } \\
\text { dezynfekcyjne }\end{array}$ & 81 & 65.9 \\
\hline disinsectization (periodically) / dezynsekcja (okresowo) & 77 & 62.6 \\
\hline deratization (periodically) / deratyzacja (okresowo) & 61 & 49.6 \\
\hline airlock at the entrance to the laboratory / śluza powietrzna w wejściu do laboratorium & 57 & 46.3 \\
\hline an observation window between rooms / okno do obserwacji pomiędzy pomieszczeniami & 8 & 6.5 \\
\hline $\begin{array}{l}\text { access to the hands-free sinks in every room / dostęp do bezdotykowej umywalki w każdym } \\
\text { pomieszczeniu }\end{array}$ & 4 & 3.3 \\
\hline eye-wash station in every room / stanowisko do płukania oczu w każdym pomieszczeniu & 4 & 3.3 \\
\hline
\end{tabular}

According to the information provided by the managers of the analysed facilities, only in two laboratories were the employees obliged to wear more than 2 pairs of gloves for specific procedures. In one of the laboratories, this protective measure applied to a microbiological laboratory, and in the second, the employees had to wear additional pairs of gloves during all of the procedures involving direct contact with biological material.

Non-slip shoes were used during laboratory work by nearly three quarters of those surveyed (92 persons, $74.8 \%$ ).

Hands-free sinks and eye-wash stations in each room were available in the laboratories of only $3.3 \%$ of those surveyed (4 persons). Showers were available in the laboratories of $90.2 \%$ of the respondents (111 persons). Surfaces resistant to acids, alkalis and disinfectants were found in the laboratories of $65.9 \%$ of those surveyed (81 persons). $68.3 \%$ of the respondents ( 84 persons) had separate lockers for work and private clothes. Airlocks at the entrances to the laboratories were available in the case of $46.3 \%$ of those surveyed (57 persons). Periodic disinsectization was carried out in the laboratories of
$62.6 \%$ of the respondents (77 persons), and deratization in the laboratories of nearly half of those surveyed (61 persons, 49.6\%).

A pass box for biological material functioned in the laboratories of only 81 persons (65.9\%), while a sample collection facility was located in a separate building in the case of $74.8 \%$ of the respondents (92 persons).

In all of the laboratories with sample collection facilities (7 laboratories), the so-called safe blood collection devices were used. However, only in 5 of them did the managers provide the names of the implemented system, and in 2 laboratories no names of the devices were given, which raises suspicions as to whether the devices were actually used in there.

According to the managers of the analysed laboratories, biological agents, including reference strains, were in most cases stored in special refrigerators or freezers (cryobanks) with access only to authorised persons.

Unfortunately, only 8 persons (6.5\%) worked in rooms with an observation window. 
Equipment made of glass (inter alia, microscope slides, containers for soaking or dying slides with preparations, beakers) was used by 92 persons $(74.8 \%)$.

Table 7 contains information on the presence of equipment in laboratories limiting direct contact with potentially infectious biological material and of automatic equipment replacing traditional work methods in laboratory diagnostics.

Such essential equipment as germicidal lamps was found in only 6 laboratories (66\%). Only 3 laboratories (33\%) had autoclaves, with one device in 1 of the facilities, and more than one autoclave with the separation of clean and dirty sterilization in 2 laboratories (22\%). Among the analysed laboratories, sterilisers using hot dry air and wash-disinfectors were available in only 2 of the facilities. Despite the fact that 6 of the investigated laboratories (66\%) were equipped with separate microbiology, virology or mycology laboratories, only 3 had laminar boxes (33\%). HEPA filters for incoming and outgoing air in the microbiological laboratory were present only in 1 laboratory (11\%). Rooms for disinfection through fumigation were also available only in 1 laboratory.
As far as devices automating work processes in laboratories are concerned, the following were found most often: automatic systems for antigen-antibody serology (5 laboratories, 55\%), automatic systems for the identification of microorganisms (4 laboratories, 44\%) and polymerase chain reaction (PCR) devices (4 laboratories, $44 \%$ ).

Among the procedures implemented in laboratories reported by managers, only 2 - hand washing/disinfection procedure and hazardous accident procedure functioned in all of the analysed facilities. Procedures for the safety of the sampling of biological material, safe handling of biological material, sterilization/disinfection of devices/equipment/surfaces, safe handling of medical waste and safe disposal of medical waste, were implemented in nearly $90 \%$ of the laboratories. Procedures for the safe transport of biological material within the laboratory were found in 6 facilities $(66 \%)$, while procedures for the inactivation of microorganisms were present in 4 laboratories (44\%). Data on the procedures implemented in the surveyed laboratories are presented in Table 8.

Table 7. Laboratory equipment limiting the risk of employees' infection

Tabela 7. Wyposażenie badanych laboratoriów w urządzenia ograniczające ryzyko zakażenia pracowników

\begin{tabular}{|c|c|c|}
\hline $\begin{array}{l}\text { Device } \\
\text { Urządzenie }\end{array}$ & \multicolumn{2}{|c|}{$\begin{array}{l}\text { Laboratories } \\
\text { Laboratoria } \\
\qquad(\mathrm{N}=9)\end{array}$} \\
\hline Germicidal lamp / Lampa bakteriobójcza & 6 & 66.7 \\
\hline Automatic system for antigen-antibody serology / Automatyczny system do serologii antygen-przeciwciało & 5 & 55.6 \\
\hline Thermal cycler / Aparat do PCR (termocykler) & 4 & 44.4 \\
\hline Autoclave / Autoklaw & 3 & 33.3 \\
\hline $\begin{array}{l}\text { two or more with a separation of clean and dirty sterilization / dwa lub więcej z rozdziałem na czystą } \\
\text { i brudną sterylizację }\end{array}$ & 2 & 11.1 \\
\hline Sterilizer with dry, hot air / Sterylizator na suche, gorące powietrze & 2 & 22.2 \\
\hline Wash-disinfector / Myjnia-dezynfektor & 2 & 22.2 \\
\hline Automatic system for blood culture / Automatyczny system do posiewów krwi & 2 & 22.2 \\
\hline Automatic system for blood group serology / Automatyczny system do serologii grup krwi & 1 & 11.1 \\
\hline HEPA filters in the laboratory / Filtry HEPA w laboratorium & 1 & 11.1 \\
\hline Laboratory disinfected by fumigation / Laboratorium odkażane przez fumigację & 1 & 11.1 \\
\hline
\end{tabular}


Table 8. The procedures implemented in the test laboratory

Tabela 8. Procedury wdrożone w badanych laboratoriach

\begin{tabular}{|c|c|c|}
\hline \multirow[t]{2}{*}{$\begin{array}{c}\text { Procedures } \\
\text { Procedura }\end{array}$} & \multicolumn{2}{|c|}{$\begin{array}{l}\text { Laboratories } \\
\text { Laboratoria } \\
\qquad(\mathrm{N}=9)\end{array}$} \\
\hline & $\mathrm{n}$ & $\%$ \\
\hline Cleaning/disinfecting hands / Mycie/dezynfekcja rąk & 9 & 100.0 \\
\hline $\begin{array}{l}\text { Procedure in the case of a hazardous accident / stabbing/needlestick injury / Procedura postępowania } \\
\text { na wypadek niebezpiecznego zdarzenia/zakłucia }\end{array}$ & 9 & 100.0 \\
\hline Safe sampling of biological material / Bezpieczne pobieranie materiału biologicznego & 8 & 88.9 \\
\hline Safe handling of biological material / Bezpieczne postępowanie z materiałem biologicznym & 8 & 88.9 \\
\hline Sterilization/disinfection devices/equipment/surface / Sterylizacja/dezynfekcja sprzętów/urządzeń/powierzchni & 8 & 88.9 \\
\hline Safe handling of medical waste / Bezpieczne postępowanie z odpadami medycznymi & 8 & 88.9 \\
\hline Safe disposal of medical waste / Bezpieczne usuwanie odpadów medycznych & 8 & 88.9 \\
\hline $\begin{array}{l}\text { Safe transport of biological material within the laboratory / Bezpieczny transport materiału biologicznego } \\
\text { w obrębie laboratorium }\end{array}$ & 6 & 66.7 \\
\hline Inactivation of microorganisms / Inaktywacja mikroorganizmów & 4 & 44.4 \\
\hline
\end{tabular}

Table 9. Employee behavior and activities that increase the risk of microorganisms occurring in workplaces Tabela 9. Zachowania pracowników i czynności zwiększające ryzyko zakażenia drobnoustrojami występującymi na stanowiskach pracy

\begin{tabular}{|c|c|c|}
\hline \multirow[t]{2}{*}{$\begin{array}{l}\text { Activities } \\
\text { Czynność }\end{array}$} & \multicolumn{2}{|c|}{$\begin{array}{l}\text { The study group } \\
\text { Badana grupa } \\
\quad(\mathrm{N}=123)\end{array}$} \\
\hline & $\mathrm{n}$ & $\%$ \\
\hline \multicolumn{3}{|l|}{ Washing the lab coat at home / Pranie fartucha w domu } \\
\hline systematically / systematycznie & 38 & 30.9 \\
\hline rarely / rzadko & 26 & 21.1 \\
\hline Eating at workstations / Spożywanie posiłków na stanowiskach pracy & 11 & 8.9 \\
\hline $\begin{array}{l}\text { Storing food in a refrigerator together with the biological material / Przechowywanie produktów spożywczych } \\
\text { w lodówce razem z materiałem biologicznym }\end{array}$ & 3 & 2.4 \\
\hline
\end{tabular}

Table 9 includes information on the number of employees who exhibited behaviour increasing the risk of infection at work. As many as $1 / 3$ of those surveyed regularly took their lab coats home to wash them (38 persons, $30.9 \%$ ). Nearly 9\% (11 persons) ate at their workstations, while $2.4 \%$ (3 persons) stored food in a refrigerator together with biological material.

\section{DISCUSSION}

The research assumptions provided for collecting data from a considerably larger group of laboratories; unfortunately, their number had to be limited due to definite refusals to participate in the survey by the managements of state facilities and the owners of private laboratories. The refusal to participate in the survey expressed by so many among the diagnostic laboratories might point to the employers' awareness of the failure to meet the standards regarding safety at work in their facilities.

In order to reduce the risk of LAI, cooperation between the employees and management of laboratories is necessary (9). The survey carried out identified problems concerning both employees (low level of knowledge on exposure and prophylaxis, not reporting exposures, behaviour increasing the risk) and employers (lack of the proper equipment and procedures for handling potentially infectious biological material, and lack of proper work organization and employee su- 
pervision). Laboratory employees and managers representing employers provided contradictory information on accidents and medical prophylaxis, which points to irregularities in these 2 areas.

The survey shows insufficient knowledge of employees on exposure to pathogenic microorganisms in their workplace, which, as admitted by the respondents themselves, definitely reduced their safety. The results of the survey on employees' knowledge on exposure to biological agents at work indicate a number of deficiencies in this field (inter alia, confusing names of microorganisms with names of antibodies or tests). Over a half of the respondents admitted the inability to specify all of the infection routes. This is particularly alarming in the context of the average seniority of the analysed population (> 20 years). Long job seniority and deficiencies in basic knowledge are associated with a routine approach to work, which increases the risk of accidents and, consequently, LAI. Moreover, the surveyed employees exhibited behaviour increasing the risk of infection: washed their protective clothing at home, ate at their workstations and stored food in a refrigerator together with biological material, which is unacceptable.

The survey results indicate a high frequency of hazardous events involving biological agents, and as many as one third of those surveyed, had at least one such accident at work. Among the respondents who experienced a hazardous accident involving a biological agent, in most cases, one such accident was identified during the entire period of employment in medical diagnostic laboratories. The results show that the occurrence of such an event increases the care and alertness of employees while performing their duties.

Analysing the results on post exposure procedures, numerous irregularities and departures from expert recommendations can be identified. This regards both the behaviour of employees who had experienced a hazardous event (only $45 \%$ reported the accident to the manager) and of managers (employees did not report accidents, because there was no reaction from the employers). Taking into account the fact that one third $(36.8 \%)$ of the accidents involving a biological agent reported by laboratory employees had taken place in 2 years preceding the survey, the lack of managers' awareness of these incidents points to the necessity of introducing systemic changes.

An antibody test for hepatitis types B and C was performed in the case of less than one third of persons who had experienced a hazardous event involving a biological agent. In order to minimise the infection risk following exposure, it is important to ensure that the time between the event and the visit to a specialist in infectious diseases is reduced to a minimum (7). In fact, out of 40 persons, who had had an accident, only $13(32.5 \%)$ saw a doctor, yet not always one specialising in the proper field.

Perhaps the situation could be improved by introducing an obligatory system of recording blood exposure among healthcare professionals, which, in consequence, would ensure that the proper post exposure procedures are applied to all of the employees. Baron and Miller (2008) argue that a national system for registering laboratory-associated infections should be introduced, and data from the register should be published on an annual basis in order to make employees aware of the scale of the risk (23).

The research shows that wearing more than one pair of gloves for some procedures substantially decreases the risk of infection in the case of an injury or stabbing (e.g. when there is high risk of spilling blood or other potentially infectious material onto the hands). This also concerns laboratory staff (32). However, the results indicate that only 2 of the 9 investigated laboratories obliged their employees to apply such a procedure. In one of the laboratories, the protection measure involved a microbiological laboratory, and in the second case, additional pairs of gloves were to be used during every procedure involving direct contact with biological material - this is unsatisfactorily low. Moreover, $7 \%$ of the respondents carried out all of their activities without gloves, which is unacceptable and shows a complete lack of supervision by the management.

Many deficiencies were also found in the case of other types of personal protection. The surveyed employees hardly ever used masks protecting the respiratory system, eye and face protection (goggles or visors). Even protective clothing was not used by the whole population (20\% worked in their private clothes). According to expert recommendations, the employees of medical diagnostic laboratories should wear long-sleeved lab coats, and in the case of handling group 3 agents, (according to Directive 2000/54/EC) with buttoned cuffs on which gloves can be worn $(2,33)$. In the survey, only $19 \%$ of the employees had such lab coats. Conversations with the managers showed that this situation was caused by financial factors.

Arranging a pass-box and sample collection facility in a separate building is aimed at reducing the employees' contact with patients, and therefore, minimising the risk of infection through the respiratory system (2). 
Such arrangements were in place in the laboratories of only approx. three quarters of the respondents.

The survey identified a low number of devices and equipment minimising the risk of infection in laboratories. This concerns both basic elements, such as disposable devices, the use of glass vessels, and others, such as hands-free sinks, eye-wash stations, germicidal lamps, autoclaves, sterilisers and laminar boxes.

Laboratories are statutorily obligated to develop and implement procedures associated with handling biological material and other biological agents at each stage of their preparation, from collection to disposal $(34,35)$. Unfortunately, regulations only include provisions on the title and subject matter of the procedure and a general statement of the duty to develop, implement and apply it. The substantive aspect must be developed individually by each facility, which raises doubts as to the correctness of these procedures.

The obtained results, in particular with regard to the behaviour of employees, do not differ significantly from other studies. Main et al. (2008) in Canada analysed the compliance of protective measures applied by laboratory staff with recommendations on preventing bloodborne viral infections (30). The results of the survey demonstrate that despite the high risk of exposure to blood-borne viruses, laboratory employees do not apply the recommendations on preventing these infections. Also the percentage of unreported exposures at work is similar to that found in the Canadian study.

The results of the research indicate that among the activities involving the highest risk of exposure there are: taking blood samples and transferring blood or other liquid biological agents from one container to another, which is consistent with EPINet data (the Exposure Prevention Information Network) (25).

\section{CONCLUSIONS}

Although the number of laboratories participating in the survey was low, the obtained information constitutes the basis for formulating the following conclusions:

1. The highest risk of infection with hazardous biological agents is associated with taking blood samples for analysis, taking cultures of biological material and opening tubes with biological material during diagnostic analyses.

2. Deficiencies were found in the employees' basic knowledge on the potential routes of infection during handling biological material, and on the health effects and proper behaviour limiting the risk of infection.
There is a necessity to increase the frequency of periodic training on health and safety at work for healthcare professionals working in diagnostic laboratories, and to extend the training programme concerning various aspects of exposure to biological agents.

3. In the surveyed group of employees, the frequency of hazardous events involving biological agents was high. Nearly one third of those surveyed experiences such an event at least once during their work in the medical diagnostic laboratory. It has been shown that less than half of the persons who had sustained an accident involving a biological agent reported this fact to the manager.

4. The individual protection measures available to employees and the equipment of laboratories with devices reducing the risk of infection should be regarded as insufficient. The analysed laboratories did not have in place all of the procedures for handling potentially infectious materials required by the applicable regulations.

\section{PIŚMIENNICTWO}

1. Centers for Disease Control and Prevention and National Institutes of Health. Biosafety in microbiological and biomedical laboratories. 5th ed. Washington: U.S. Government Printing Office; 2007.

2. Health Services Advisory Committee. Safe working and the prevention of infection in clinical laboratories and similar facilities. 2nd ed. Richmond: HSE Book; 2003.

3. UK Department of Health and DEFRA. Biological agents: Managing the risks in laboratories and healthcare premises. Norwich: The Stationary Office; 2005.

4. Health Services Advisory Committee. The management, design and operation of microbiological containment laboratories. 1st ed. Richmond: HSE Book; 2001.

5. World Health Organization. Laboratory biosafety manual. 3rd ed. Geneva: WHO; 2004.

6. Occupational Safety and Health Administration, U.S. Department of Labor. Laboratory safety guidance, 2011 [cited 2013 Jul 31]. Available from: https://www.osha.gov/ Publications/laboratory/OSHA3404laboratory-safetyguidance.pdf.

7. Panlilio AL, Cardo DM, Grohskopf LA, Heneine W, Ross CS. Updated U.S. Public Health Service guidelines for the management of occupational exposures to HIV and recommendations for postexposure prophylaxis. MMWR Morb Mortal Wkly Rep. 2005;54(RR-9):1-17 [cited 2013 Jul 31]. Available from: http://www.cdc.gov/ $\mathrm{mmwr} / \mathrm{PDF} / \mathrm{rr} / \mathrm{rr} 5409$.pdf. 
8. Centers for disease control and prevention. Updated U.S. Public Health Service guidelines for the management of occupational exposures to HBV, HCV, and HIV and recommendations for postexposure prophylaxis. MMWR Morb Mortal Wkly Rep. 2001;50(RR-11):1-52 [cited 2013 Jul 31]. Available from: http://www.cdc.gov/ $\mathrm{mmwr} / \mathrm{PDF} / \mathrm{rr} / \mathrm{rr} 5011 . p d f$.

9. Miller JM, Astles R, Baszler T, Chapin K, Carey R, Garcia $\mathrm{L}$, et al. Guidelines for safe work practices in human and animal medical diagnostic laboratories. Recommendations of a CDC-convened, biosafety blue ribbon panel. MMWR Morb Mortal Wkly Rep. 2012;61(Suppl):1-102 [cited 2013 Jul 31]. Available from: http://www.cdc.gov/ mmwr/pdf/other/su6101.pdf.

10. Thomas WJC, Murray JRD. The incidence and reporting rates of needle-stick injury amongst UK surgeons. Ann R Coll Surg Engl. 2009;91(1):12-7, http://dx.doi. org/10.1308/003588409X359213.

11. Jagger J. Are Australia's healthcare workers stuck with inadequate needle protection? The most direct way to reduce percutaneous injuries is to make devices safer. Med J Aust. 2002;177(8):405-6.

12. Elmiyeh B, Whitaker IS, James MJ, Chahal CA, Galea A, Alshafi K. Needle-stick injuries in the National Health Service: A culture of silence. J R Soc Med. 2004;97(7): 326-7, http://dx.doi.org/10.1258/jrsm.97.7.326.

13. Mir O, Adam J, Veyrie N, Chousterman B, Gaillard R, Gregory $\mathrm{T}$, et al. Accidental blood exposures among medical residents in Paris, France. Clin Microbiol Infect. 2011;17(3):464-6, http://dx.doi.org/10.1111/j.14690691.2010.03321.x.

14. Monge V, Mato G, Mariano A, Fernández C, Fereres J, GERABTAS Working Group. The Spanish Group Registry of Biological Accidents in Healthcare Workers. Epidemiology of biological-exposure incidents among Spanish healthcare workers. Infect Control Hosp Epidemiol. 2001;22(12):776-80, http://dx.doi.org/10.1086/ 501862.

15. Rybacki M, Piekarska A, Wiszniewska M, WalusiakSkorupa J. [Work safety among polish health care workers in respect of exposure to bloodborne pathogens]. Med Pr. 2013;64(1):1-10. Polish.

16. Smoliński P, Serafińska S, Gładysz A. [Underestimation of exposure incidence rates in polish health workers: A prospective study]. Med Pr. 2006;57(6):507-16. Polish.

17. Nasim S, Shahid A, Mustufa MA, Arain GM, Ali G, Taseer IU, et al. Biosafety perspective of clinical laboratory workers: A profile of Pakistan. J Infect Dev Ctries. 2012;6(8):611-9, http://dx.doi.org/10.3855/ jidc.2236.
18. Elduma AH. Assessment of biosafety precautions in Khartoum state diagnostic laboratories, Sudan. Pan Afr Med J. 2012;11:19.

19. Okwara EC, Enwere OO, Diwe CK, Azike JE, Chukwulebe AE. Theatre and laboratory workers' awareness of and safety practices against hepatitis $\mathrm{B}$ and $\mathrm{C}$ infection in a suburban university teaching hospital in Nigeria. Pan Afr Med J. 2012;13:2.

20. Özsahin A, Demir M, Zencir M, Demir S, Kaleli I. Safety awareness among laboratory workers. Adv Ther. 2006;23(3):414-20, http://dx.doi.org/10.1007/ BF02850162.

21. Kalaskar A, Vasanthi G. Needlestick Injuries among Laboratory Technicians in Diagnostic Laboratories of Kanyakumari District, India. Al Ameen J Med Sci. 2011;4(4):348-51.

22. Baron EJ, Miller JM. Bacterial and fungal infections among diagnostic laboratory workers: evaluating the risks. Diagn Microbiol Infect Dis. 2008;60(3):241-6, http://dx.doi.org/10.1016/j.diagmicrobio.2007.09.016.

23. Singh K. Laboratory-Acquired Infections. Clin Infect Dis. 2009;49(1):142-7, http://dx.doi.org/10.1086/599104.

24. Sejvar JJ, Johnson D, Popovic T, Miller JM, Downes F, Somsel P, et al. Assessing the risk of laboratory-acquired meningococcal disease. J Clin Microbiol. 2005;43(9): 4811-4, http://dx.doi.org/10.1128/JCM.43.9.4811-4814.2005.

25. Jagger J, Perry J, Parker G. Lab workers: Small group, big risk. Nursing. 2003;33(1):72, http://dx.doi. org/10.1097/00152193-200301000-00049.

26. Walker D, Campbell D. A survey of infections in United Kingdom laboratories, 1994-1995. J Clin Pathol. 1999;52(6): 415-8, http://dx.doi.org/10.1136/jcp.52.6.415.

27. Traxler RM, Guerra MA, Morrow MG, Haupt T, Morrison J, Saah JR, et al. Review of brucellosis cases from laboratory exposures in the United States, 2008-2011, and improved strategies for disease prevention. J Clin Microbiol. 2013;51(9):3055-62, http://dx.doi.org/10.1128/ JCM.00813-13.

28. Bouza E, Sánchez-Carrillo C, Hernangómez S, González MJ. Spanish Co-operative Group for the Study of Laboratory-acquired Brucellosis. Laboratoryacquired brucellosis: A Spanish national survey. J Hosp Infect. 2005;61(1):80-3, http://dx.doi.org/10.1016/j.jhin. 2005.02.018.

29. Herwaldt BL. Laboratory-acquired parasitic infections from accidental exposures. Clin Microbiol Rev. 2001;14(4):659-88, http://dx.doi.org/10.1128/CMR. 14.3.659-688.2001.

30. Main CL, Carusone SC, Davis K, Loeb M. Compliance with personal precautions against exposure to blood- 
borne pathogens among laboratory workers: A Canadian survey. Infect Control Hosp Epidemiol. 2008;29(1):66-8, http://dx.doi.org/10.1086/524325.

31. Parszuto J, Jaremin B, Bardoń A, Obuchowska A. [Occupational HBV and HCV infections among health care workers]. Med Pr. 2012;63(4):441-52. Polish.

32. Peichl P. Health, safety and environmental protection in a biological research laboratory. Int Arch Occup Environ Health. 2000;73(Suppl):8-13, http://dx.doi.org/10.1007/ PL00014632.

33. Directive 2000/54/EC of the European Parliament and of the Council of 18 September 2000 on the protection of workers from risks related to exposure to biologi- cal agents at work (Seventh individual directive within the meaning of Article 16(1) of Directive 89/391/EEC). Off J EU L 262 (2000).

34. [The Ordinance of the Minister of Health of 23 March 2006 on the quality standards for medical diagnostic and microbiological laboratories]. Journal of Laws of 2006 no. 61, item 435. Polish.

35. [The Ordinance of the Minister of Health of 22 April 2005 on biological factors harmful for human health in the workplace environment and the protection of the health of employees occupationally exposed to these agents]. Journal of Laws of 2005 no. 81, item 716. Polish.

This work is available in Open Access model and licensed under a Creative Commons Attribution-NonCommercial 3.0 Poland License / Ten utwór jest dostępny w modelu open access na licencji Creative Commons Uznanie autorstwa - Użycie niekomercyjne 3.0 Polska - http://creativecommons.org/ licenses/by-nc/3.0/pl. 